\title{
Plausibility of Hydrocarbon Potential Analytics of Archie's Model by Cementation Factor Pliability in Shaly Sand Reservoir
}

\author{
Anthony John.Ilozobhie ${ }^{1, *}$ and Daniel Ikechukwu Egu ${ }^{2}$ \\ ${ }^{1}$ Physics Department, University of Calabar \\ Nigeria \\ ${ }^{2}$ Petroleum Department,,Madona University \\ Nigeria \\ *Corresponding author's email: anthonyilozobhie [AT] gmail.com
}

\begin{abstract}
Comprehensive comparative analyses of 18 shaly sandstone zones in four wells of an Oil Field in the Niger Delta were carried using only the Archie Model with the appropriate cementation factor from a range of 1.3 to 2.0 This was done to comprehensively analyze and statistically validate the need for the applicability of $m=1.3$. Detailed statistical analysis of water saturation results of lower and upper 95\% confidence intervals for the standard deviations gave the least range of 0.00415 to $0.00724(\mathrm{~m}=1.3), 0.00660$ to $0.1151(\mathrm{~m}=1.65)$ and maximum of 0.00996 to 0.01747 $(m=2.0)$. This was however validated by the bias results of the standard deviation with -0.00025 for $m=1.3,-0.00040$ for $m=1.65$ and $\mathbf{- 0 . 0 0 0 6 0}$ for $m=2$. Hydrocarbon saturation results of lower and upper $95 \%$ confidence intervals for the standard also gave the least values of 0.00427 to $0.00740(\mathrm{~m}=1.3), 0.00680$ to $0.01171(\mathrm{~m}=1.65)$ and 0.01031 to 0.01773 $(m=2.0)$. The bias results of the standard deviation gave the least for $m=1.3$ as $-0.0002,-0.00032$ for $m=1.65$ and 0.00048 for $m=2.0$. Hydrocarbon movability index results of lower and upper $95 \%$ confidence intervals for standard deviation gave the least range for $m=1.3$ of 0.00521 to $0.00934,0.00793$ to 0.01415 for $m=1.65$ and 0.01155 to 0.02049 for $m=2.0$. The bias results of the standard deviation gave also the least for $m=1.3$ as $-0.00031,-0.00047$ for $m=1.65$ and -0.00068 for $m=2$. The study reveals that the Archie Model predictions was improved with cementation factor of 1.3 and has favourable petrophysical parameters indicating higher hydrocarbon potential than the Simandoux and when $m=1.65$ and 2.0. This model is a valuable tool in a shaly sand environment after thorough validation using the pickett plot.
\end{abstract}

Keywords--- Archie Models, cementation factor, porosity, hydrocarbon, water saturations

\section{INTRODUCTION}

Detailed petrophysical evaluation involves a comprehensive qualitative and quantitative evaluation of the chemical and physical characteristics of rocks and fluids garnished by vigorous application of rock physics data and theory (Aigbediou and Iyayi, 2007 and Ilozobhie, et.al. 2009). It is however important to note that to thoroughly validate any petrophysical interpretation assertions, all dependent and independent variables related to all its critical models must be critically reassessed to improve estimation of fluid saturations (Ellis, 1987; Ellis, Singer, 2008 and Ilozobhie and Obi, 2010).

Archie's law states that the rock matrix is non-conductive which means that for sandstone with clay minerals, this assumption is no longer valid in general due to the clay structure and cation ionic exchange capacity (Archie 1942, 1950 and 1952). The Waxman Smits equation is one model that tries to correct for this anomaly (Lee and Collett, 2006). The cementation factor or rock matrix shape factor is not a constant but a variable depending on many physical parameters and lithological attributes of porous media (Ipek, 2002 and Ilozobhie, et. al 2015). The cementation factor (m) of the Archie's equation is highly dependent on porosity, rock type, size, shape of grains and pore throats. This trend is more proactive in shaly sands where incursions of shales in sand reservoirs reduces porosities and increases degree of cementation. Archie (1947) experimentally quantified the degree of cementation of rock matrix using the factor ' $\mathrm{m}$ ' where he concluded that for consolidated sandstones it has a range of 1.8 to 2.5 and decreased to 1.3 for unconsolidated sandstones as is the case in the Niger Delta, southern Nigeria (Chevron 1996). Sequel to this, the unconsolidated shaly sand reservoirs of the Niger 
Delta connotes that the appropriate cementation factor should be 1.3 and not the 2.0 currently applied by companies in Nigeria and most logging and petrophysical firms (Kumiawan, 2002 and Ilozobhie and Egu, 2019). Continuous application of cementation factor of 2.0 has given rise to errors in the estimation of critical petrophysical parameters such as the formation factor $(F)$, water saturation $\left(S_{\mathrm{w}}\right)$, hydrocarbon saturation $\left(\mathrm{S}_{\mathrm{h}}\right)$, water of flushed zone $\left(\mathrm{S}_{\mathrm{xo}}\right)$, residual hydrocarbon saturation $\left(\mathrm{s}_{\mathrm{hr}}\right)$, movable oil saturation (MOS), bulk volume water (BVW) and hydrocarbon movability index (HMI).

However, the aim of this study is to reevaluate all the petrophysical fluid properties of 18 different shaly sand zones in Four oil wells drilled on the same reservoir located in the Niger Delta, Nigeria by sensitizing different cementation factors for unconsolidated, mid-consolidated and consolidated shaly sands with very low amounts of shale incursions. The objective is actually to investigate the relationship between reservoir porosities and critical petrophysical properties using different cementation factors $(\mathrm{m})$ of $1.3,1.65$ and 2 . This was done to comprehensively analyze and statistically validate the need for the applicability of $\mathrm{m}=1.3$.

\section{ARCHIE'S MODEL}

In sedimentary rocks, the Archie's model relates porosity and saturation of brine to in-situ electrical conductivity using the equation;

$C_{t}=\frac{1}{a} C_{w} \varnothing^{m} S_{w}^{n}$

Where $\Phi$ is the porosity, $\mathrm{C}_{\mathrm{t}}$ is the electrical conductivity of the fluid saturated rock, $\mathrm{C}_{\mathrm{w}}$ is the electrical conductivity of the brine, $S_{w}$ is the saturation of brine, $m$ is the cementation exponent of the rock ( $m=1.8$ to 2.0 for sand stones), $n$ is the saturation exponent ( $\mathrm{n}$ is approximately equal to 2.0 ) and a is the tortuosity. The reciprocal of the electrical conductivity gives;

$R_{t}=a \emptyset^{-m} S_{w}^{-n} R_{w}$

The Resistivity index is the ration of the true resistivity $\left(\mathrm{R}_{\mathrm{t}}\right)$ to the resistivity of the rock filled with only water $\left(\mathrm{R}_{\mathrm{o}}\right)$ and given as;

$I=\frac{R_{t}}{R_{o}}=S_{w}^{-n}$

Archie's law was developed as an empirical qualitative relationship between porosity, electrical conductivity and brine saturation of rocks. Consequently, modern well log interpretation foundation was laid and it encompasses borehole electrical conductivity and resistivity measurements to hydrocarbon saturations where for rocks saturated with fluids, $S_{\mathrm{o}}=$ $1-\mathrm{S}_{\mathrm{w}}$ (Dewan, 1982).

\subsection{Cementation exponent}

The cementation exponent describes or models the impact of the pore network increase with the resistivity as the rock while the matrix is assumed to be non-conductive. If the pore network are modeled as sets of parallel capillary tubes, a cross sectional area average of the rock's resistivity would produce porosity dependence equivalent to a cementation of 1.0 but the tortuosity of the rock increases this to a higher number than 1.0. This makes the rock permeability independent of the cementation exponent.

The exponent is approximately 1.3 for unconsolidated sands and increases with degree of cementation to a range of 1.8 to 2.0 in consolidated sandstones. However, in carbonate rocks, they show higher variance due to strong diagenetic affinity and complex pore structures to a range of 1.7 to 4.1 and the cementation does not depend on temperature.

\subsection{Saturation exponent}

The saturation exponent is approximately 2.0 and it models the dependency on the presence of non-conductive fluid (hydrocarbon) in the pore space and is related to the wettability of the rock.

\subsection{Tortuosity factor (a)}

The tortuosity factor also called the lithology coefficient, lithologic factor or cementation intercept is applied to correct variations in compaction, grain size and pore structure (Schlumberger, 1972). It is related to the current flow path length and its value is in the range of 0.5 to 1.5 and may vary in different reservoirs.

\subsection{Measurement of the exponents}

In petrophysics, the most accepted and reliable source for numerical value of $\mathrm{m}$ and $\mathrm{n}$ exponents is through experiments from sand plugs from cored wells. The brine conductivity and the cementation exponent can also be inferred from downhole electrical conductivity measurements across brine saturated intervals. Hence plotting the logarithm of the 
measured in-situ electrical conductivity against the logarithm of the measured in-situ porosity (Pickett plot), according to Archie's law, a straight line is produced of which the slope is equal to the cementation exponent and intercept equal to the logarithm of the in-situ brine conductivity (Rider 1999).

\section{MATERIALS AND METHOD}

The data used consist of four well log suites comprising of gamma ray, resistivity, neutron and density logs. Qualitative interpretation was done by identifying lithologies such as sands (low gamma readings) and shale zones (high gamma readings) using the gamma ray logs. Fluid identification for hydrocarbon and/or water bearing zones was identified within the sand zone using the resistivity logs where high and low resistivities denotes hydrocarbons and brine water zones (Schlumberger, 1972 and Hamada 1999). The neutron-density logs although used for natural gas identification but in the absence of gas was used for estimation of total porosities which was used to estimate the effective porosities. Quantitative evaluation of porosities in all the identified reservoir sand zones was done using the porosity evaluation guide shown in Table 1. The porosities for each sand zones identified was then used to estimate the formation factors using the Archie's model as shown in equation 4 below.

$F=a \emptyset^{-m}=\frac{R_{o}}{R_{w}}$

Where; $\mathrm{a}=$ tortuosity factor $(\mathrm{a}=1) ; \mathrm{R}_{\mathrm{o}}$ is the resistivity of the rock filled with only water $\left(\mathrm{S}_{\mathrm{w}}=1\right)$. $\mathrm{m}=$ cementation factor and $\mathrm{m}=1.3$ for unconsolidated sands and $\mathrm{m}=1.8$ to 2.5 for consolidated sands.

Table 1: Qualitative Evaluation of Porosity in Reservoir Rocks (Ulasi et al., 2012).

\begin{tabular}{ccc}
\hline Sand zones & $\begin{array}{c}\text { Percentage porosity } \\
(\%)\end{array}$ & $\begin{array}{c}\text { Qualitative } \\
\text { evaluation }\end{array}$ \\
\hline 1. & $0-5$ & Negligible \\
2. & $5-10$ & Poor \\
3. & $15-20$ & Good \\
4. & $20-30$ & Very good \\
5. & $\geq 30$ & Excellent \\
\hline
\end{tabular}

Water saturation analysis was calculated using water saturation from the Archie's model (Archie, 1942) as shown in equation 5 .

$S_{w}=\sqrt{\frac{F \times R_{w}}{R_{t}}}$

Where; $\mathrm{R}_{\mathrm{W}}=$ resistivity of the formation water; $\mathrm{R}_{\mathrm{t}}=$ true formation resistivity; $\mathrm{F}=$ formation factor.

Bulk volume water $(B V W)$ which is the product of the effective porosity $(\varnothing)$ and water saturation $\left(S_{\mathrm{w}}\right)$ was calculated using equation 6 (Asquith and Gibson 1982).

$B V W=\emptyset S_{w}$

Hydrocarbon saturation $\left(\mathrm{S}_{\mathrm{h}}\right)$ which is a function of the water saturation was calculated using equation 7 (Asquith and Gibson 1982).

$S_{h}=1-S_{w}$

Water of flushed zone $\left(\mathrm{S}_{\mathrm{XO}}\right)$ which is the square root of the water saturation was estimated by applying equation 8(Asquith and Gibson, 1982). 
Residual hydrocarbon saturation ( $\mathrm{S}_{\mathrm{hr}}$ ) was obtained by using equation 9 (Asquith and Gibson, 1982).

$S_{h r}=1-S_{x o}$

Movable oil saturation (MOS) was calculated from equation 10(Asquith and Gibson, 1982).

$\operatorname{MOS}=S_{x o}-S_{w}$

Hydrocarbon Movability Index (HMI) which is the ratio of the water saturation to the water of flushed zone was calculated from equation 11(Asquith and Gibson, 1982).

$H M I=\frac{S_{w}}{S_{x o}}$

Comprehensive computer programs was developed using Microsoft excel spread sheet using the average effective porosity estimation as input data for quick estimation of the formation factor $(F)$, water saturation $\left(S_{\mathrm{w}}\right)$, bulk volume water (BVW), hydrocarbon saturation $\left(S_{h}\right)$, water of flushed zone $\left(S_{x o}\right)$, residual hydrocarbon saturation $\left(S_{h r}\right)$, movable oil saturation (MOS) and hydrocarbon movability index (HMI).

\section{RESULTS AND DISCUSSION}

Results of petrophysical evaluation for cementation factor of 1.3 and computed with average effective porosity range for wells $\mathrm{A}, \mathrm{B}, \mathrm{C}$ and $\mathrm{D}$ in the 18 sandy shale reservoirs of 0.24 to 0.34 and this was applied to obtain a range of 4.06515779 to 6.39330445 for formation factor $(\mathrm{F}), 0.081709065$ to 0.102469408 for water saturation $\left(\mathrm{S}_{\mathrm{w}}\right), 0.024592658$ to 0.918290935 for hydrocarbon saturation $\left(S_{h}\right), 0.60597408$ to 0.634043195 for water of flushed zone $\left(S_{x o}\right), 0.365956805$ to 0.39402592 for hydrocarbon saturation $\left(S_{h r}\right), 0.524265015$ to 0.531573787 for movable oil saturation and 0.134839207 to 0.161612662 for hydrocarbon movability index (HMI) as shown in Table 2 and figure 1 . This estimation were also computed for the average cementation factors of 1.65 and a maximum index of 2 as shown in Table 3, Figure 2, Table 4 and Figure 3.

Table 2: Petrophysical results for $\mathrm{m}=\mathbf{1 . 3}$

\begin{tabular}{|c|c|c|c|c|c|c|c|c|c|c|}
\hline कचाI. & ZONY & phi & F & Sw & BVWV & Sh & Sro & Shr & MOS & HMII \\
\hline \multirow{4}{*}{ A } & AAl & 0.3 & 7.29037604 & 0.1094225 & 0.0325267 & 0.3905775 & 0.6424233 & 0.3575767 & 0.5330009 & 0.1703277 \\
\hline & AA2 & 027 & 367480682 & 01193593 & 003222 & 0.3506407 & 0.6536592 & 0.3403105 & 0.3343285 & 0.1825934 \\
\hline & $A+3$ & 0.25 & 9.34915331 & 0.1271836 & 0.0317939 & 0.8728164 & 0.662043 & 0.337957 & 0.5345394 & 0.1921077 \\
\hline & AA4 & 0.24 & 10.3334102 & 0.1315395 & 0.0313696 & 0.8684602 & 0.6665173 & 0.3334527 & 0.5349775 & 0.1973539 \\
\hline \multirow{5}{*}{ B } & AAl & 0.29 & 7.7093034 & $0.112526 !$ & 0.0326326 & 0.3574739 & 0.646027 & 0.353973 & 0.5335009 & 0.1741817 \\
\hline & A.12 & 0.34 & 5.93006955 & 0.0956673 & 0.0335537 & 0.9013127 & 0.6292921 & 0.3707079 & 0.5306045 & 0.1568228 \\
\hline & AA3 & 03 & $72903760 \mathrm{~F}$ & 01054225 & 0.0325267 & 0.3905775 & 0.6434233 & 0.3575767 & 0.5330009 & 0.1703277 \\
\hline & AAS & 0.25 & 9.34915331 & 0.1271836 & 0.0317999 & 0.8728164 & 0.662043 & 0.337957 & 0.5345394 & 0.1921077 \\
\hline & A.AS & 0.24 & 10.5334102 & 0.1315395 & 0.0315696 & 0.5684602 & 0.6665173 & 0.3334527 & 0.3349775 & 0.1973539 \\
\hline \multirow{4}{*}{ c } & AAI & 0.28 & 3.16933283 & 0.1153314 & 0.0324328 & 0.8541656 & 0.6497783 & 0.3502217 & 0.533947 & 0.1782629 \\
\hline & A.12 & 0.3 & 7.29037604 & 0.1094225 & 0.0325267 & 0.8905775 & 0.6424233 & 0.3575767 & 0.5330009 & 0.1703277 \\
\hline & $\mathrm{AAB}^{3}$ & 029 & 7.7093034 & 0.121261 & 0.0351538 & 08587739 & $0.6 \$ 6027$ & 0353973 & 0.5335009 & 0.1741517 \\
\hline & AA4 & 0.27 & 8.67460662 & 0.1193593 & 0.032227 & 0.8306407 & 0.6536592 & 0.3453108 & 0.5343253 & 0.1525934 \\
\hline \multirow{5}{*}{ D } & A.41 & 0.24 & 10.5334102 & 0.1325395 & 0.0315696 & 0.8684602 & 0.6665173 & 0.3334527 & 0.5342775 & 0.1973539 \\
\hline & A.42 & 0.26 & 9.23196131 & 0.1231342 & 0.0320149 & $0.87685: 3$ & 0.6577725 & 0.3422275 & 0.5346353 & 0.1871987 \\
\hline & $A+A^{3}$ & 0.29 & 7.7090034 & 0.1125261 & 0.0326326 & 0.3574739 & 0.646027 & 0.353973 & 0.5335009 & 0.1741817 \\
\hline & AA4 & 0.3 & 7.29037604 & 0.1094225 & 0.0328267 & 0.3905775 & 0.6424233 & 0.3575767 & 0.5330000 & 0.1703277 \\
\hline & A.AS & 0.29 & 7.7095034 & 0.1125261 & 0.0326326 & 0.8574739 & 0.646027 & 0.353973 & 0.5335009 & 0.1741317 \\
\hline
\end{tabular}




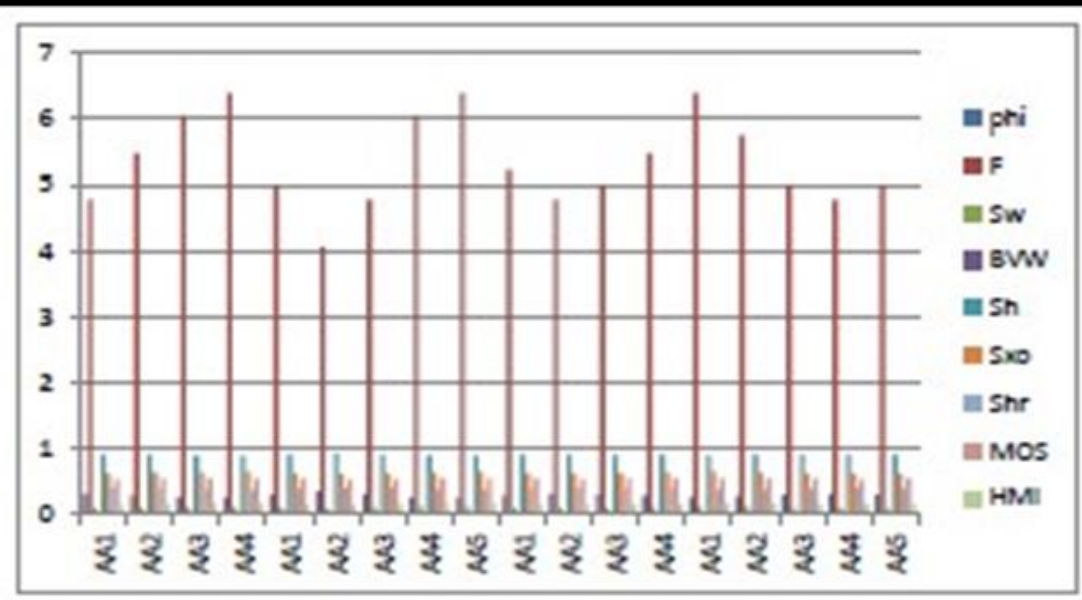

Fig. 1: Results of $m=1.3$

Table 3: Petrophysical results for $\mathrm{m}=\mathbf{1 . 6 5}$

\begin{tabular}{|c|c|c|c|c|c|c|c|c|c|c|}
\hline NEII & ZONE & $\mathrm{pbi}$ & $F$ & Sw & BVW & $\mathrm{Sh}$ & Sro & Star & MOS & HMII \\
\hline \multirow{4}{*}{$\mathbf{A}$} & AAl & 0.3 & 7.29037604 & 0.1094225 & 0.0325267 & 0.8905775 & 0.6424233 & 0.3575767 & 0.5330009 & 0.1703277 \\
\hline & $\mathrm{AA}_{2}$ & 027 & 8.67400602 & 0.1193593 & 003222 & $0.8506+5$ & 0.6536552 & $0.3+53105$ & $0.53+3285$ & 0.1523934 \\
\hline & $\mathrm{A}+3$ & 0.25 & 9.54915331 & 0.1271836 & 0.0317959 & 0.8728164 & 0.662043 & 0337957 & 0.5345994 & 0.1921077 \\
\hline & AAA & 0.24 & 10.5334102 & 0.1315395 & 0.0313696 & 0.8654502 & 0.6665173 & 0.3334827 & 0.5349775 & 0.1973339 \\
\hline \multirow{5}{*}{ B } & AAl & 0.29 & 7.7095034 & 0.1125261 & 0.0326326 & 0.8574739 & 0.645027 & 0.353973 & 0.5333009 & 0.1741817 \\
\hline & $A A_{2}$ & 0.34 & 5.93006955 & 0.0956573 & 0.0335337 & 0.9013127 & 0.6292921 & $0.37070 \times 9$ & 0.5306048 & 0.1565228 \\
\hline & $\mathrm{AA3}$ & 03 & 7.29037604 & 0.109425 & 0.032826 & $0.85057 m$ & $0.642+233$ & 0.3575767 & 0.5330009 & 0.170327 \\
\hline & AMA & 0.25 & 9.84915531 & 0.1271836 & 0.0317959 & 0.8728164 & 0.662043 & 0.337957 & 0.5345394 & 0.1921077 \\
\hline & $\overline{A+5}$ & 0.24 & 10.3334102 & 0.1315396 & 0.0315696 & 0.8654502 & 0.66651773 & 0.3334627 & 0.534975 & 0.1973539 \\
\hline \multirow{4}{*}{ c } & AA1 & 0.28 & 8.16938283 & 0.1153314 & 0.0324325 & 0.8841656 & 0.6497783 & 0.3502217 & 0.533947 & 0.1782629 \\
\hline & $\mathrm{AA2}$ & 0.3 & \begin{tabular}{|l}
7.29037604 \\
\end{tabular} & 0.1094225 & 0.0328267 & 0.8905775 & 0.6424233 & 0.3575767 & 0.5330009 & 0.1703277 \\
\hline & $\mathrm{A}+3$ & 0.29 & 7.7095034 & 01125261 & 0.0326326 & 0.8574739 & $0.6 \$ 5027$ & 0333973 & $0.533 \times 009$ & 0.1741517 \\
\hline & AA4 & 0.27 & 3.67460662 & 0.1193993 & 0.032227 & 0.8506407 & 0.6536592 & $0.3+63108$ & 0.5343296 & 0.1529934 \\
\hline \multirow{5}{*}{ D } & AAl & 0.24 & 10.5334102 & 0.1315395 & 0.0313696 & 0.8684502 & 0.6665173 & 0.3334827 & 0.5349775 & 0.1973339 \\
\hline & $A+2$ & 0.26 & 9.23196131 & 0.1231342 & 0.0320149 & 0.8768558 & 0.637725 & 0.3422275 & 0.5346353 & \begin{tabular}{|l|}
0.1871937 \\
\end{tabular} \\
\hline & $\mathrm{AA3}$ & 0.29 & 7.7095034 & 0.1125261 & 0.0326326 & 0.8574739 & 0.645027 & 0.353973 & 0.5333009 & \begin{tabular}{|l|}
0.1741817 \\
\end{tabular} \\
\hline & AAA & 0.3 & \begin{tabular}{|l}
7.29037604 \\
\end{tabular} & 0.1094225 & 0.0328267 & 0.8505775 & 0.6424233 & 0.3575767 & 0.5330009 & 0.1703277 \\
\hline & $\overline{A A S}$ & 0.29 & 7.7095034 & 0.1125261 & 0.0326326 & 0.8574739 & 0.646027 & 0353973 & 0.5333009 & 0.1741817 \\
\hline
\end{tabular}

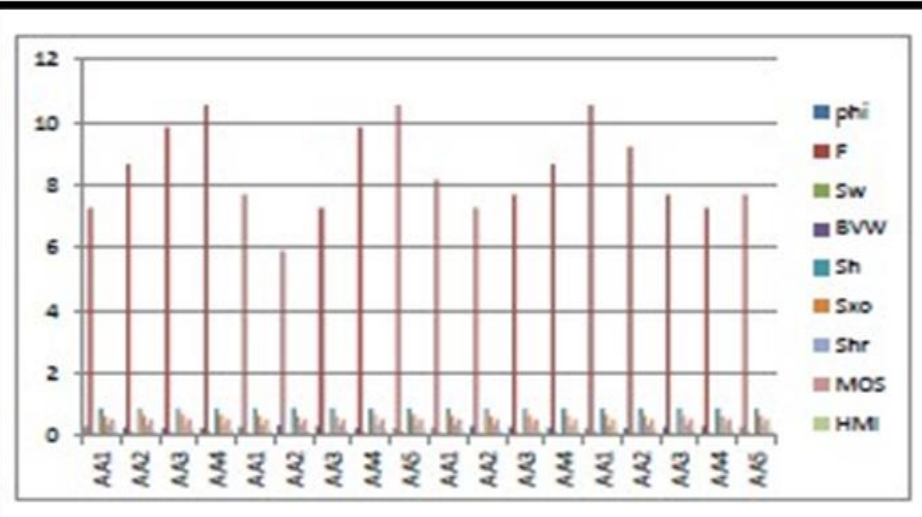

Fig. 2: Results of $m=1.65$

Table 4: Petrophysical results for $m=\mathbf{2 . 0}$ 

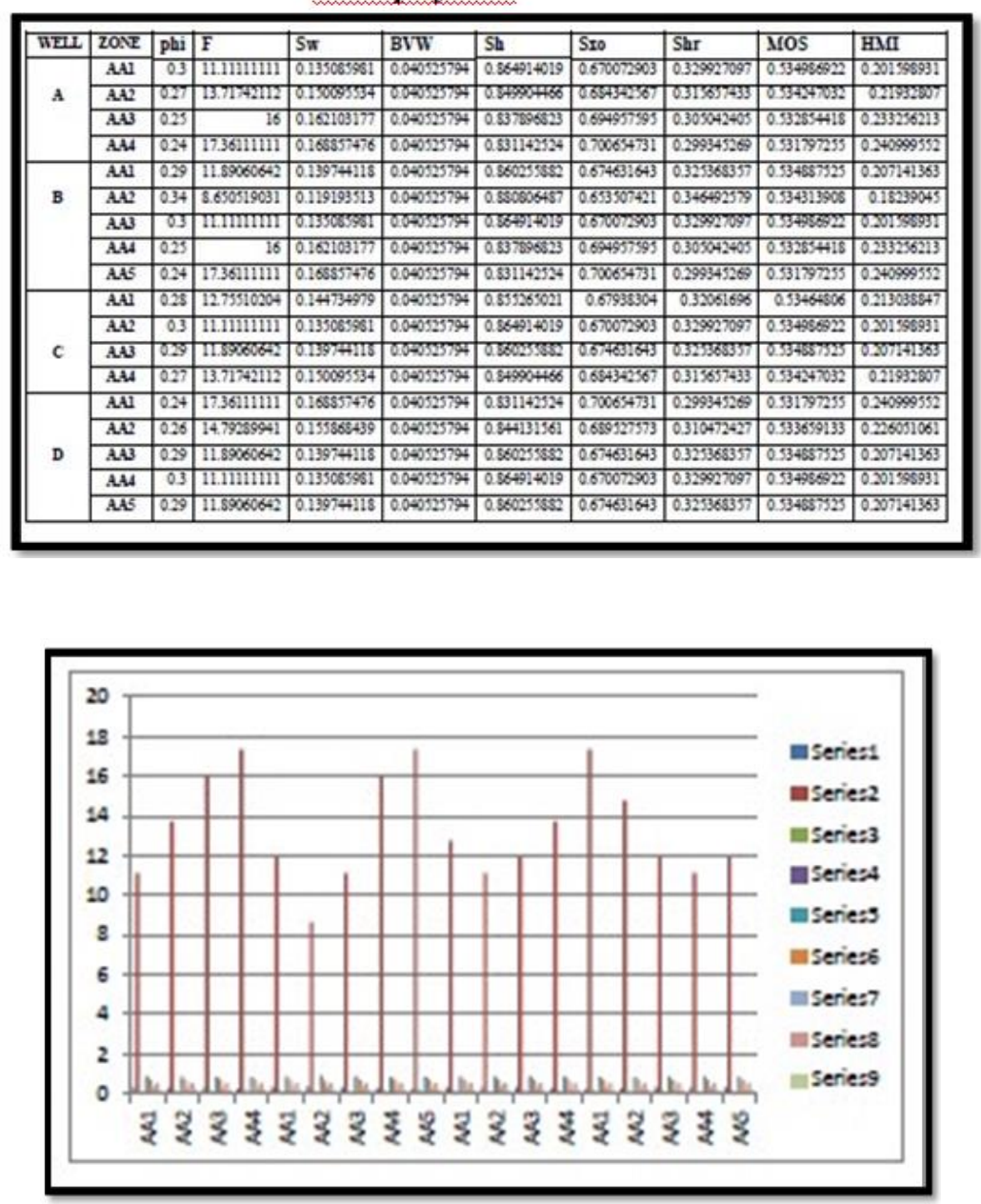

Fig. 3: Results of $m=2.0$

Comparative analytical evaluation of water saturation revealed that the results for cementation factors of $1.3,1.65$ and 2 gave range of 0.081709065 to $0.102469408(\mathrm{~m}=1.3), 0.0986873$ to $0.1315398(\mathrm{~m}=1.65)$ and 0.135085981 to 0.168857476 $(\mathrm{m}=2.0)$ revealing that cementation factor of 1.3 relationship of water saturation with porosity is appropriate and not as high as $m=2.0$ as shown in Figures 4 and 5.

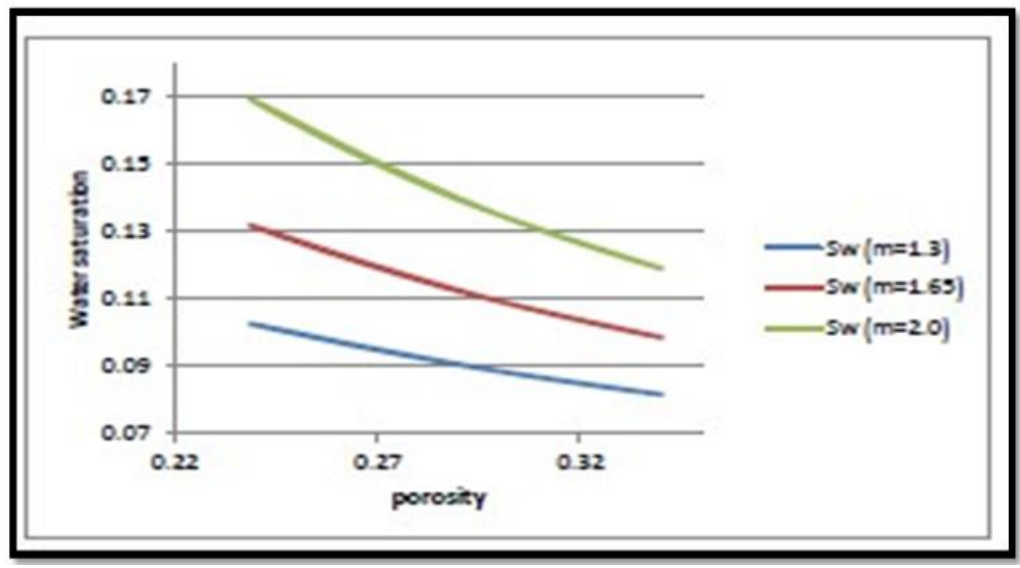

Fig. 4: Water saturation and porosity results (a) 


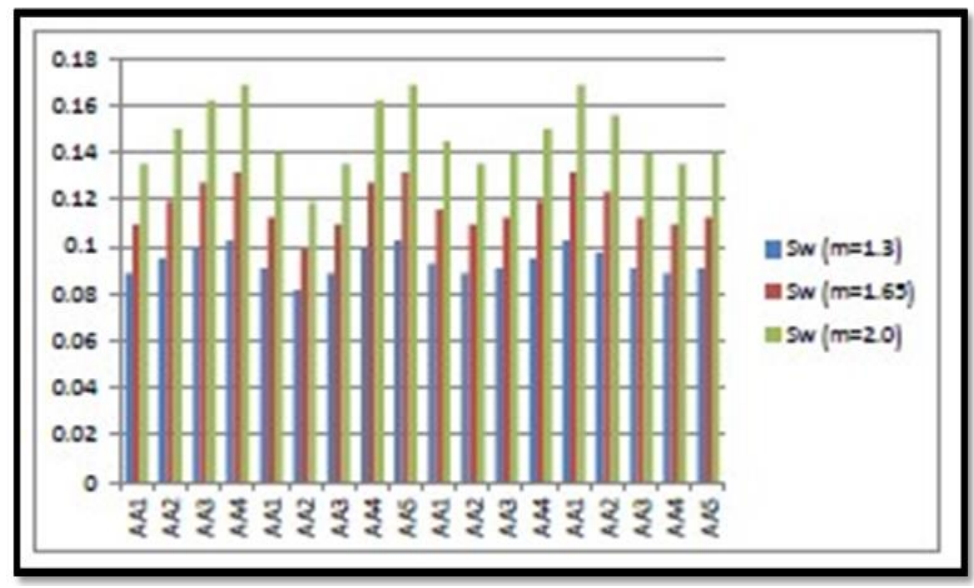

Fig. 5: Water saturation results of all zones (b)

Hydrocarbon saturation $\left(\mathrm{S}_{\mathrm{h}}\right)$ results gave a range of 0.897530592 to $0.918290935(\mathrm{~m}=1.3), 0.8684602$ to $0.9013127(\mathrm{~m}=1.65)$ and 0.831142524 to $0.880806487(\mathrm{~m}=2.0)$ revealing also the choice of $\mathrm{m}=1.3$ as maximum hydrocarbon saturation with porosity as shown in Figures 6 and 7. Flushed zone water saturation $\left(\mathrm{S}_{\mathrm{xo}}\right)$ result gave a range of 0.60597408 to 0.634043195 (m 1.3), 0.6292921 to $0.6665173(\mathrm{~m}=1.65)$ and 0.670072903 to $0.700654731(\mathrm{~m}=2.0)$ revealing the least trend of $\mathrm{m}=1.3$ as flushed zone water saturation varies with porosity as shown in Figures 8 and 9 . Residual hydrocarbon saturation $\left(\mathrm{S}_{\mathrm{hr}}\right)$ results gave a range of 0.365956805 to 0.39402592 (m 1.3), 0.3334827 to 0.3707079 $(\mathrm{m}=1.65)$ and 0.299345269 to $0.346492579(\mathrm{~m}=2.0)$ revealing the same stable trend but of least linear increasing pattern with average effective porosities of $\mathrm{m}=1.3$ indicating better prediction of uncertainties as shown in Figures 10 and 11 . Movable oil saturation (MOS) results gave a range of 0.524265015 to 0.531573787 ( $\mathrm{m}=1.3), 0.5306048$ to 0.5349775 $(\mathrm{m}=1.65)$ and 0.531797255 to $0.534986922(\mathrm{~m}=2.0)$ revealing appropriate least inverse trend for $\mathrm{m}=1.3$ followed by $\mathrm{m}=1.65$ but it was unusually an increasing polynomial functional trend for $\mathrm{m}=2.0$ as shown in Figures 12 and 13 . This means there is a direct impact of higher degree of cementation factor of the rock matrix on the movable oil saturation with respect to the porosity. Hydrocarbon movability index (HMI) results gave a range of 0.134839207 to $0.16162662(\mathrm{~m}=1.3)$, 0.1568228 to $0.1973539(\mathrm{~m}=1.65)$ and 0.18239045 to $0.240999552(\mathrm{~m}=2.0)$ validating the choice of the least inverse HMI trend with porosity for $\mathrm{m}=1.3$ as shown in Table 2, Figures 14 and 15.

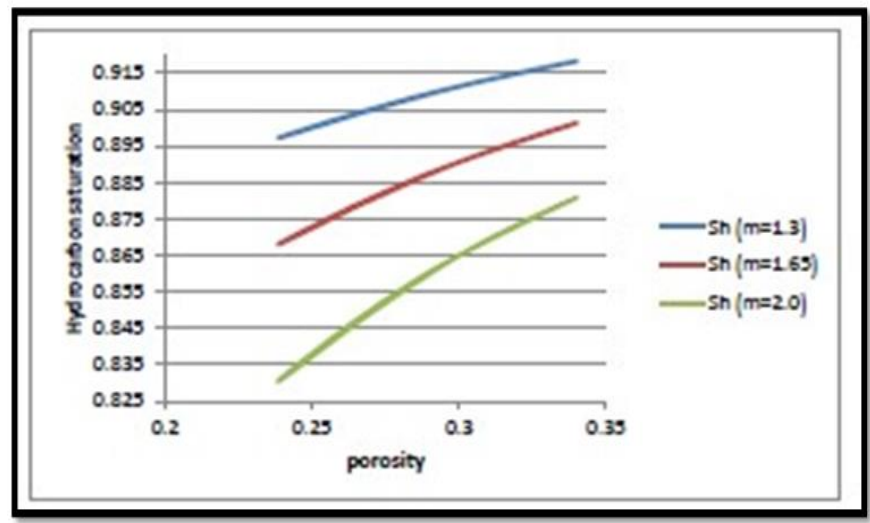

Fig. 6: Hydrocarbon saturation and porosity results (a) 


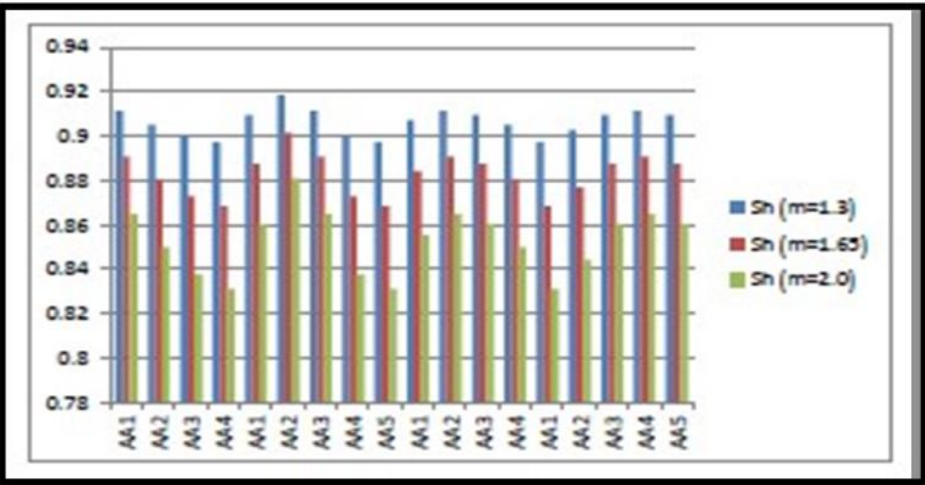

Fig. 7: Hydrocarbon saturation results of all zones (b)

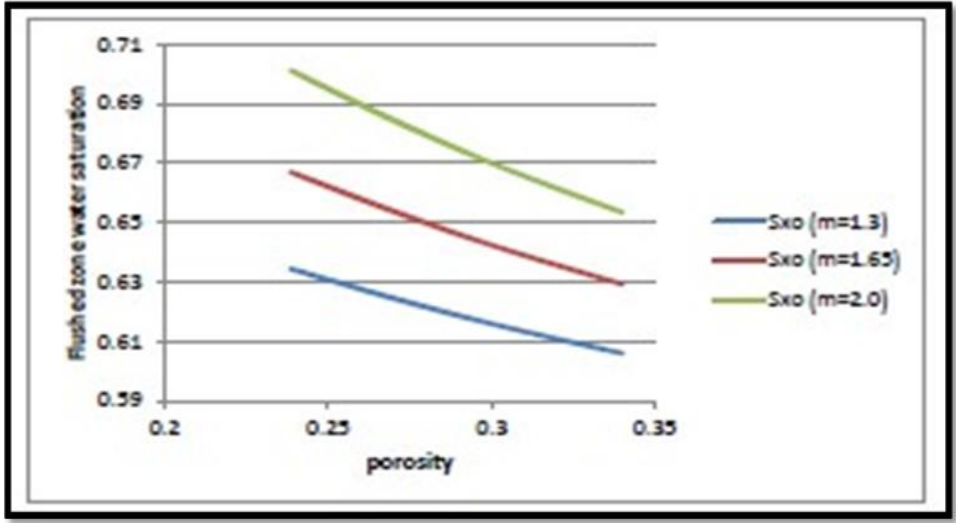

Fig. 8: Flushed zone water saturation and porosity results (a)

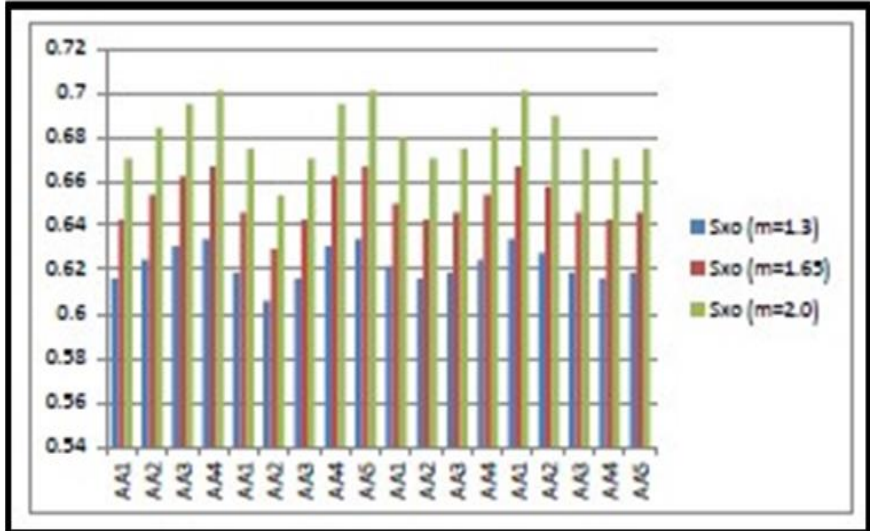

Fig. 9: Flushed zone water saturation results of all zones (b)

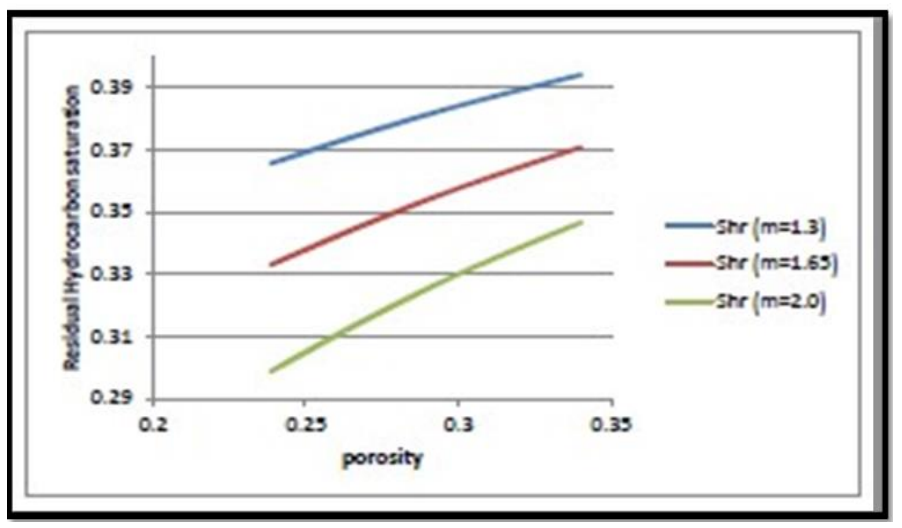

Fig. 10: Residual hydrocarbon saturation and porosity results (a) 


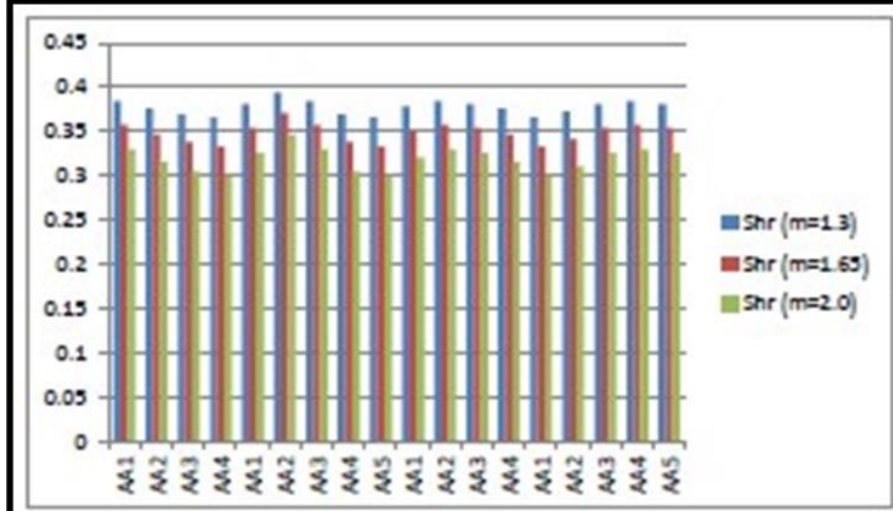

Fig. 11: Residual hydrocarbon saturation results of all zones (b)

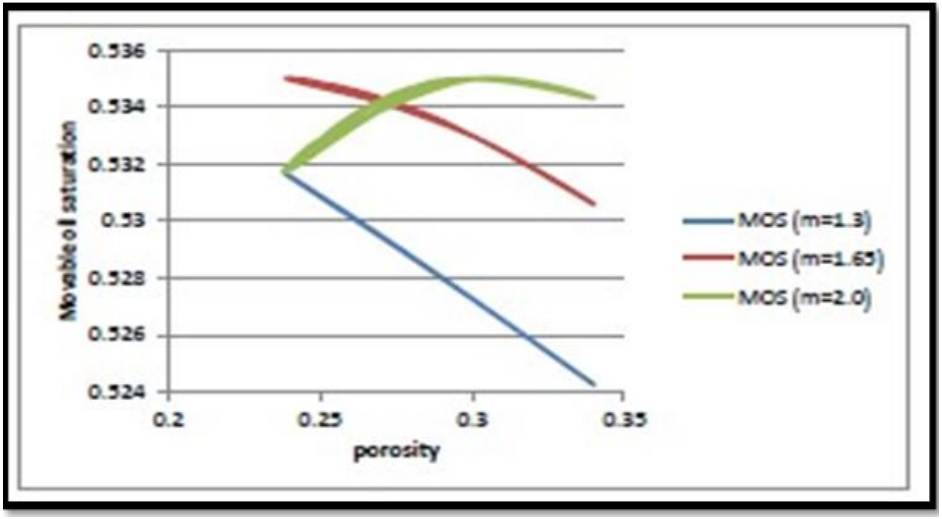

Fig. 12: Moveable oil saturation and porosity results (a)

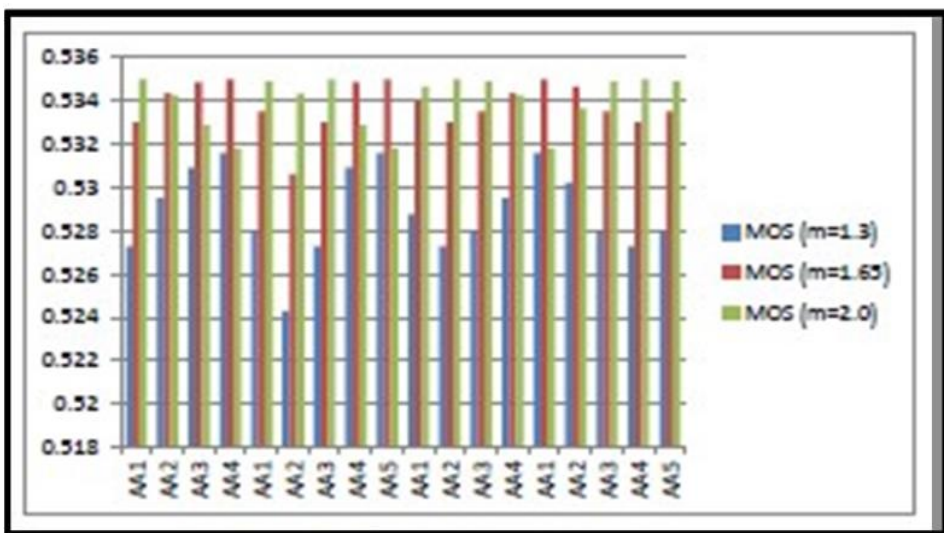

Fig. 13: Moveable oil saturation results of all zones (b) 


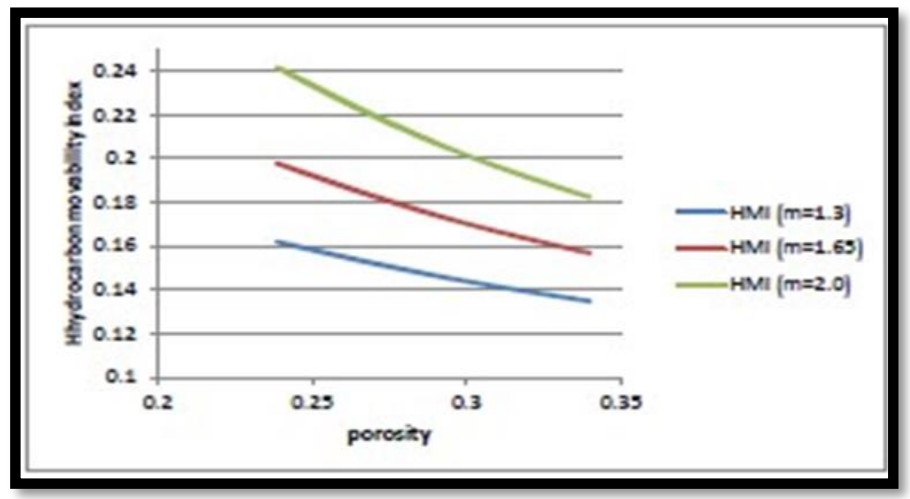

Fig. 14: Hydrocarbon movability index and porosity results (a)

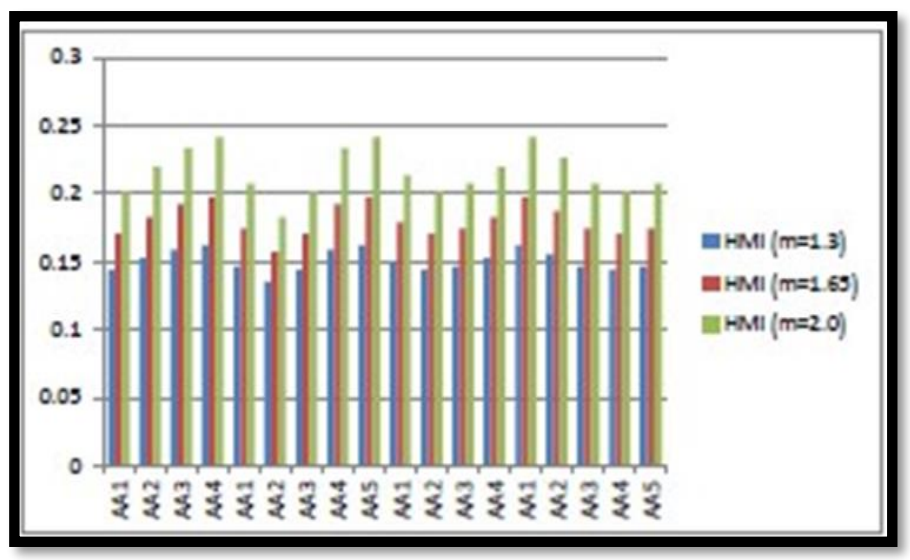

Fig. 15: Hydrocarbon movability index results of all zones (b)

However, a robust re-evaluation of the results was carried out again for water saturation, hydrocarbon saturation, movable oil saturation and hydrocarbon movability index with a view of technically establishing the degree of confidence of choice of $\mathrm{m}=1.3$ for this study. Sequel to this, water saturation results of lower and upper $95 \%$ confidence intervals for the standard deviations gave the least range of 0.00415 to $0.00724(\mathrm{~m}=1.3), 0.00660$ to $0.1151(\mathrm{~m}=1.65)$ and maximum of 0.00996 to $0.01747(\mathrm{~m}=2.0)$. This was however validated by the bias results of the standard deviation with -0.00025 for $\mathrm{m}=1.3,-0.00040$ for $\mathrm{m}=1.65$ and -0.00060 for $\mathrm{m}=2$ as shown in Table 5. Hydrocarbon saturation results of lower and upper $95 \%$ confidence intervals for the standard also gave the least values of 0.00427 to $0.00740(\mathrm{~m}=1.3), 0.00680$ to 0.01171 $(\mathrm{m}=1.65)$ and 0.01031 to $0.01773(\mathrm{~m}=2.0)$. The bias results of the standard deviation gave the least for $\mathrm{m}=1.3 \mathrm{as}-0.0002$, -0.00032 for $\mathrm{m}=1.65$ and -0.00048 for $\mathrm{m}=2.0$ as shown in Table 6 .

Table 5: Statistical water saturation results

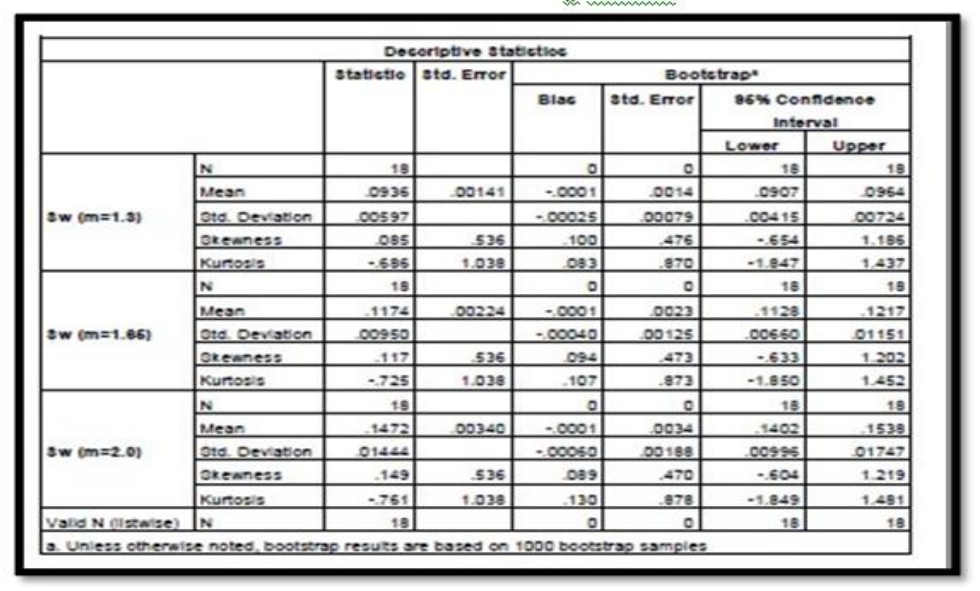


Table 6: Statistical hydrocarbon saturation results

\begin{tabular}{|c|c|c|c|c|c|c|c|}
\hline \multicolumn{8}{|c|}{ soltaldets avitgtnojea } \\
\hline \multicolumn{4}{|c|}{ coets:1009 } & \multirow[t]{3}{*}{ nona .010 } & \multirow[t]{3}{*}{ sdstese } & & \\
\hline Evasinl 9: & gormos pae & roma bac & sele & & & & \\
\hline nageu & nowes & & & & & & \\
\hline ar & $8 \mathrm{r}$ & 0 & 0 & & ar & $n$ & \multirow{5}{*}{$(\varepsilon . t=m) 20 \mathrm{M}$} \\
\hline Tesa. & etsa. & 3000. & 0000. & $T 2000$. & eesa. & nes: & \\
\hline zasoo. & teroo. & rco0o. & e00000.- & & eeroo. & nodteiva & \\
\hline ate. & 30 r.t- & sea. & 205 & aca. & ac. & scamonase & \\
\hline $000 s$ & aas.r- & $8 a 0, t$ & aac- & $8 \varepsilon 0, t$ & 320. & Elsonux & \\
\hline ar & ar & 0 & 0 & & ar & $n$ & \multirow{5}{*}{ (29. $\mathrm{t}=\mathrm{m}) \mathrm{\varepsilon ON}$} \\
\hline Eaca. & sece. & 5000. & 0000. & 25000. & acca. & nes:M & \\
\hline aaroo & aapoo. & asooo. & 70000 - & & trrog. & nodtevalo bic & \\
\hline $\operatorname{sen}$. & ore.t- & aАT. & aez & acz. & are.t- & 230 monace & \\
\hline gasa & se8.r- & ees:- & ara.r- & $8 \varepsilon 0.1$ & 2285 & $z \sin u x$ & \\
\hline et & ar & 0 & 0 & & at & a & \multirow{5}{*}{$(0 . s=m) s 0 \mathrm{~m}$} \\
\hline a2sa. & acce. & 6000. & 0000. & es000. & oaca. & nesM & \\
\hline $2 a+\infty$ & arooo. & eroog. & 20000 - - & & $r=r 00$ & noldevad ore & \\
\hline ter.- & ores:- & таз. & $580-$ & acz. & $100.1-$ & ssamases & \\
\hline ere.a & $4.9 .1-$ & Tae.t & ras. & esco.t & gaz- - & Elsonux & \\
\hline at & sor & 0 & 0 & & er & n & (osinsallo И bllev \\
\hline
\end{tabular}

Movable oil saturation (MOS) results of lower and upper 95\% confidence intervals for the standard deviation however gave the least range for $m=1.65$ of 0.00066 to $0.00155,0.00075$ to $0.00144(\mathrm{~m}=2.0)$ and maximum of 0.00137 to 0.00252 for $m=1.3$ while the bias results of the standard deviation gave the least for $m=2.0$ as $-0.00004,-0.00007$ for $m=1.65$ and maximum of -0.00009 for $\mathrm{m}=1.3$ as shown in Table 7 . Hydrocarbon movability index results of lower and upper $95 \%$ confidence intervals for standard deviation gave the least range for $\mathrm{m}=1.3$ of 0.00521 to $0.00934,0.00793$ to 0.01415 for $\mathrm{m}=1.65$ and 0.01155 to 0.02049 for $\mathrm{m}=2.0$ as shown in Table 8 . The bias results of the standard deviation gave also the least for $\mathrm{m}=1.3$ as $-0.00031,-0.00047$ for $\mathrm{m}=1.65$ and -0.00068 for $\mathrm{m}=2$.

Table 7: Statistical movable oil saturation results

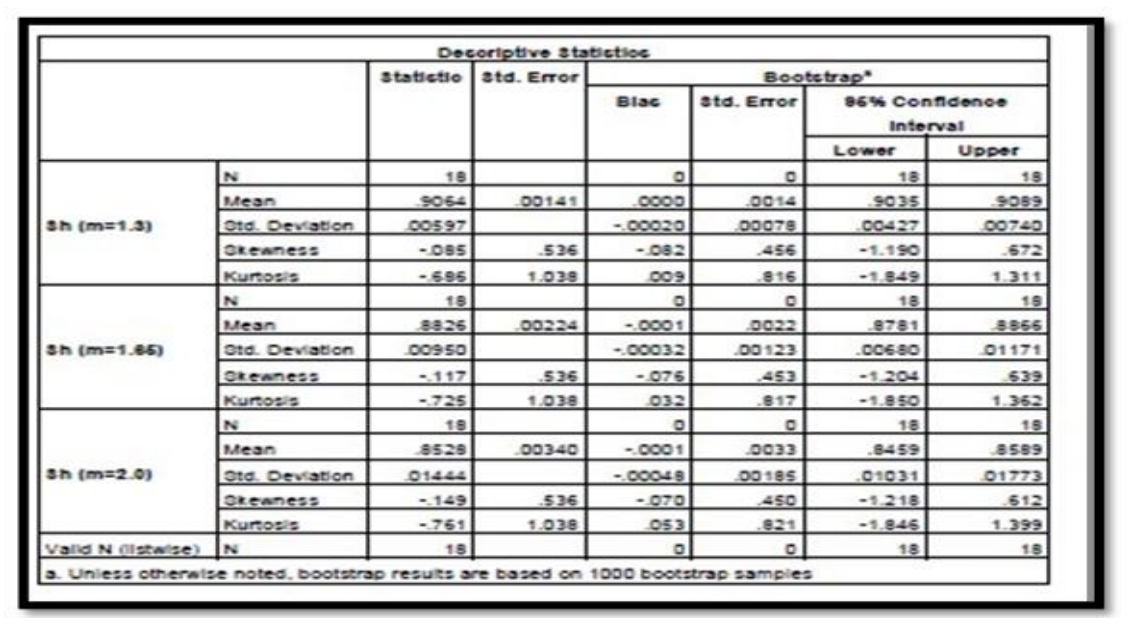

Table 8: Statistical hydrocarbon movability index results

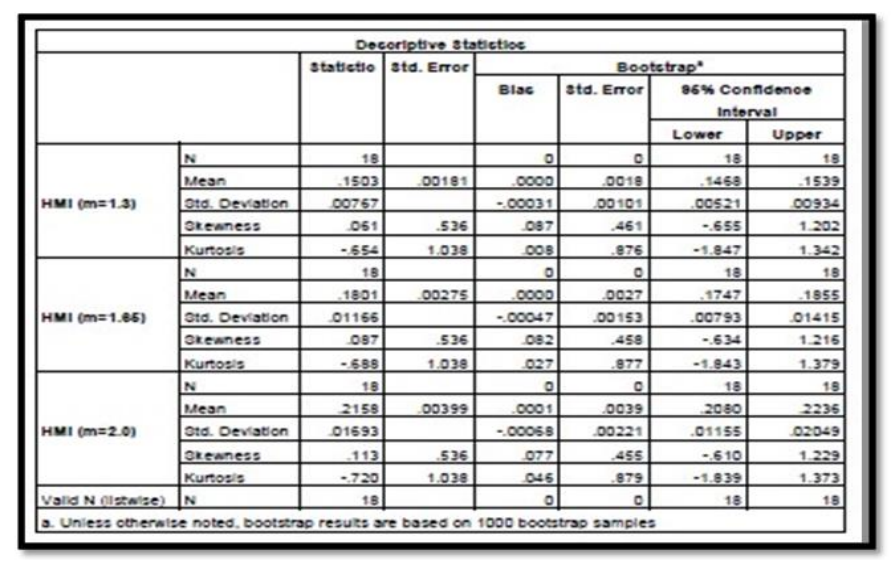




\section{CONCLUSION}

This study has clearly shown that the formation factor, water saturation, water of flushed zone, movable oil saturation and hydrocarbon movable index have the same lower and upper limits in sand zones AA2 (well B) to maximum sand zones AA4 (well A), AA5 (well B) and AA1 (well D) for $\mathrm{m}=1.3$ while this trend was similar to results of $\mathrm{m}=1.65$ but different for $\mathrm{m}=2.0$ where the lower limits occurred in sand zones AA1 (well A), AA3 (well B), AA2 (well C) and AA4 (well D) but only for formation factor $(F)$, water saturation $\left(S_{\mathrm{w}}\right)$ and water of flushed zone saturation $\left(S_{\mathrm{xo}}\right)$. Bulk volume water $(B V W)$, hydrocarbon saturation $\left(S_{h}\right)$ and residual hydrocarbon saturation $\left(S_{\mathrm{hr}}\right)$ depicts lower and upper limits in sand zones for m=1.3 and 1.65 from AA4 (well A), AA5 (well B) and AA1 (well D) to a maximum of AA2 (well B). When $\mathrm{m}=2.0$, the trend was similar for hydrocarbon saturation $\left(\mathrm{S}_{\mathrm{h}}\right)$ and residual hydrocarbon saturation $\left(\mathrm{S}_{\mathrm{hr}}\right)$ but the bulk volume water (BVW) was relatively constant revealing the degree of degrading confidence. Furthermore, with $\mathrm{m}=2.0$, the movable oil saturation (MOS) and hydrocarbon movability index (HMI) deviated from the usual trends of $m=1.3$ and 1.65 . For the movable oil saturation (MOS), the least values changed from sand zone AA2 (well B) in m=1.3 and 1.65 to three zones of AA4 (well A), AA5 (well B) and AA1 (well D) while the three earlier maximum values of AA4 (well A), AA5 (well B) and AA1 (well D) varied to four maximum values from sand zones AA1 (well A), AA3 (well B), AA2 (well C) and AA4 (well D). These remarkable heterogeneous disparities in the increased degree of hydrocarbon movability are an indication of uncertainties technically hinged on fluctuations in the degree of cementation of the rock matrix. The results were however of the same trend with hydrocarbon movability index but relatively higher. This means that the most sensitive shaly sand reservoirs in this study for $\mathrm{m}=1.3$ and 1.65 are AA4 (well A), AA2 (well B), AA5 (well B) and AA1 (well D) but with $\mathrm{m}=2.0$, additional zones were AA1 (well A), AA3 (well B), AA2 (well C) and AA4 (well D) while the bulk volume water $(\mathrm{BVW})$ is constant for all values of porosity and water saturation meaning that for cementation factors higher than 1.65, the formation factor becomes independent of the cementation factor with adverse effects on the hydrocarbon movability index (HMI) and movable oil saturation (MOS).

\section{GEOPHYSICAL IMPLICATION}

This study has clearly shown the impact of the pliability of cementation in shaly sand reservoir for vigorous plausibility of hydrocarbon potentials particularly for $\mathrm{m}=2.0$ which is initially intended for consolidated reservoirs and the possible infusions of shales should not be used as a criteria for its applicability for petrophysical analytics. Cementation factors of $\mathrm{m}=1.3$ should be applied for unconsolidated shaly sand reservoirs and care should be taken to increase it depending on the field data available. Earlier publications such as Adeoti et al (2015) should be reviewed and re-evaluated using m=1.3 and reevaluating the shale content and volume before considering the application of the Waxman Smits equation and validating the vigorous comparisons, this would virtually enhance the sense of value of the research findings as depicted by the results of this research.

\section{REFERENCES}

- Adeoti, L. Ojo, A. A., Olatinsu, O. B., Fasakin O. O. and Adesanya, O. Y. (2015). Comparative Analysis of Hydrocarbon Potential in Shaly Sand Reservoirs using Archie and Simandoux Models: A Case Study of "X" Field, Niger Delta, Nigeria. Ife Journal of Science vol. 17, no.1.

- Aigbedion, I. and Iyayi, S.E. (2007). Formation Evaluation of Oshioka Field Using Geophysical Well Log, MiddleEastJournal of Scientific Research,2(4), pp.107-110.

- Archie, G.E. (1942). "The electrical resistivity $\log$ as an aid in determining some reservoir

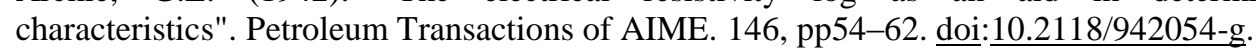

- Archie, G.E. (1947). "Electrical resistivity an aid in core-analysis interpretation". American Association of Petroleum Geologists Bulletin. 31 (2), pp 350-366.

- Archie, G.E. (1950). "Introduction to petrophysics of reservoir rocks". American Association of Petroleum Geologists Bulletin. 34 (5), pp943-961. doi:10.1306/3d933f62-16b1-11d7-8645000102c1865d.

- Archie, G.E. (1952). "Classification of carbonate reservoir rocks and petrophysical considerations". American Association of Petroleum Geologists Bulletin. 36 (2): pp.278-298. doi:10.1306/3d9343f7-16b1-11d7$\underline{8645000102 \mathrm{c} 1865 \mathrm{~d}}$.

- Asquith, G. and Gibson, C. (1982). Basic Well Log Analysis and for Geologists. American Association of Petroleum Geologists, Tulsa, Oklahoma. pp. 216.

- Chevron (1996). Sandstone Reservoir Evaluation: Sandstone Characteristics. Presented at the Intermediate Formation Evaluation Seminar held in Ibadan, Nigeria. August25 - 31. Pp. 1 - 44.

- Dewan, J. T. (1983). Essentials of Modern Open-Hole Log Interpretation. Penn Well Publishing Company, Tulsa, Oklahoma, USA. pp361.

- Hamada, G.M. (1999). An Integrated Approach to determine shale volume of hydrocarbon potential in Shaly Sand, Proceedings of the SPWLA held in Houston, Texas, May-June, pp. 1-25.

- $\quad$ Ellis, D. V. (1987). Well Logging for Earth Scientists. Elsevier. ISBN 0-444-01180-3. 
- Ellis, D. V. and Singer, J. M. (2008). Well Logging for Earth Scientists (Second ed.). Springer. Pp. 692. ISBN 14020-3738-4.

- Ilozobhie, A.J. Obi, D.A and Okwueze, E.E (2015) Geostatistical analysis of porosity distribution from well log data, in part of Bornu Basin, North- eastern part, Nigeria using Kriging and Co- Kriging methods. Advances in Applied Science Research Vol. 6(2), pp.83-95

- Ilozobhie, A.J. Okwueze, E.E and Egeh, E.U (2009) Sand- Shaliness Evaluation of Part of Bornu Basin Using well log data. Nigerian Journal of Physics, Vol.21(1), pp. 53-62.

- Ilozobhie, A.J and Obi, D.A (2010) The Visual basic plotter manager: meeting the challenges of well log digital data conversion. International journal f Natural and Applied Sciences Vol 6 (1\$2), pp.77-89

- Ilozobhie, A.J. and Egu, D.A (2019) Formation Temperature Distribution of the Turonian-Maastrichtian Fika Shale Formation from Wireline Logs in Part of Borno Basin, Northeastern Nigeria. Asian Journal of Applied Sciences 7(5) pp.642-652

- Ipek, G. (2002). Log Derived Cation Exchange Capacity of Shaly Sands: Application to Hydrocarbon Detection and Drilling Optimization. Faculty of the Louisiana State University and Agricultural andMechanical College, Louisiana. pp.167.

- Kurniawan, T. (2002). Evaluation of the Hydrocarbon Potential in Low-Salinity Shaly Sand. Graduate Faculty of the Louisiana State University and Agricultural and Mechanical College, Louisiana. pp.94.

- Lee, M.W. and Collett, T.S. (2006). A Method of ShalySand Correction for Estimating gas Hydrate Saturations using Downhole Electrical Resistivity Log Data. U.S. Geological Survey Scientific InvestigationsReport20065121, pp. 4-14.

- Rider, Malcolm H. (1999). The Geological Interpretation of Well Logs (Second ed.). Whittles Publishing Services. pp. 288. ISBN $\underline{0-9541906-0-2}$.

- Schlumberger (1972). Log Interpretation Volume 1: Principles. Schlumberger Limited, New York. 113.

- Ulasi, I., Onyekuru, O. and Iwuagwu, C. J. (2012). Petrophysical Evaluation of UzekWell using Well Log and Core Data, Offshore Depobelt, Niger Delta, Nigeria, Advances in Applied Science Research, 3 (5), pp.1-26. 